Катедра за неохеленске студије

predrag.mutavdzic@ fil.bg.ac.rs

\title{
О ВАЖНОСТИ АКЦЕНТА У НАСТАВИ САВРЕМЕНОГ ГРЧКОГ КАО СТРАНОГ ЈЕЗИКА ${ }^{1}$
}

АПСТРАКТ: Према правописном решењу, свака двосложна и вишесложна реч савременог грчког језика треба да буде обележена само једним акцентом (акутом) и то на оном месту на које пада. За разлику од компликованог система бележења акцената у античком грчком, систем бележења акцентуације у савременом је знатно једноставнији, али то не значи да нема својих компликација. Писање грчког акцента усваја се аутоматски, са речима и њиховим правописом, што ће рећи да је акценат њен саставни графички, акустички и морфолошки сегмент. Главна особина грчког акцента је његова велика динамичност (покретљивост) унутар три могућа места која може имати у речима. Сва правила акцентуације се директно усвајају путем одговарајућих морфолошких облика речи. Приликом подучавања грчког као страног наставник треба да помогне својим студентима (полазницима) да што лакше и једноставније усвоје знања у вези с акцентом и његовом позицијом.

Кључне речи: савремени грчки, акцент, монотонски систем, правила, динамичност, морфологија.

\section{ON THE IMPORTANCE OF ACCENT IN TEACHING MODERN GREEK AS A FOREIGN LANGUAGE}

ABSTRACT: According to the rules of the accentuation of Modern Greek, every word which consists of two and more syllables must be written with the acute accent above the syllable which carries the stress. Unlike the complicated system of accentuation in Ancient Greek, the system of accentuation of Modern Greek is much simpler, but still somewhat complicated. The writing of the Greek stress is acquired automatically with words and their spelling, meaning that accent is part of the word as is it graphological, acoustic and morphological segment. The main feature of Greek stress is its dynamicity within three possible positions in words. All the rules of stress are directly acquired through morhpological forms of words. When teaching Greek as a foreign language the teacher should help his students to acquire the knowledge of the position of stress as easily as possible.

Keywords: modern Greek, stress, monotonic system, rules, dynamicity, morphology.

\footnotetext{
1 Рад је написан у оквиру пројекта Министарства просвете, науке и технолошког развоја Републике Србије Језиции и културе у времену и простору, број 178002.
} 


\section{1. УВОДНИ ДЕО}

До 1982. године према важећим одредбама правописа у савременом

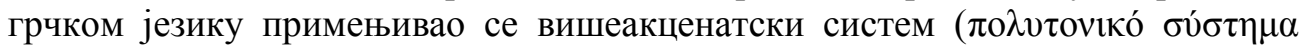

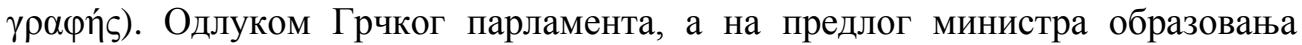

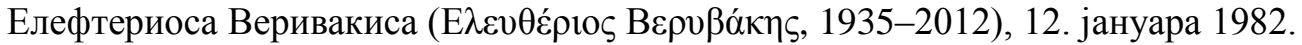

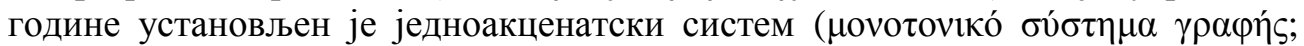
ПВ, 1982). Као главни разлог за покретање овакве реформе у правопису било је образложење министра да су се у међувремену - тачније речено, кроз историјски развој савременог грчког од антике па до нашег доба - потрле све оне кључне фонетске разлике које су се уочавале између грчких акцената. Сва

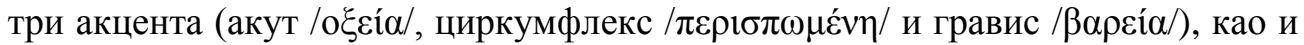
оба хака ( $\pi v \varepsilon v ́ \mu \alpha \tau \alpha)$, у литератури познатија под латинским називима spiritus asper $(\delta \alpha \sigma \varepsilon i ́ \alpha)$ и spiritus lenis ( $\psi \imath \lambda \eta ́)$, писани су искључиво по традицији. Њих je, као што је добро познато, први увео током хеленистичког периода у грчку

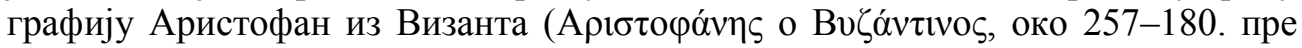
Христа; Vendryes, 1945: 8), оснивач Александријске библиотеке, чувени граматичар и филолог. Његов графички систем за обележавање акцената одговарао је понајпре прозодији античке грчке поезије: увођењем посебних дијакритичких знакова изнад самогласника желео је да укаже на потребу за правилним изговором (наглашавањем) слогова током казивања (читања) поетског текста. Ово је било у неку руку нужно, будући да је, како тврде Браунинг (Browning, 1995: 40-42) и Тоне (Tonnet, 1984: 10-11), већ у његово време грчки акценат хеленистичке којне показивао тежњу ка своме и квантитативном и квалитативном упрошћавању: како су наступиле поступне промене у изговору самогласника и дифтонга, тако су се почеле губити дужине и аспирације самогласника. Са друге стране,

„задржавање акцената и аспирација само као пуких графичких симбола било је излишно и изазивало је озбиљне проблеме у писању. Зато је одлучено да се уклоне и да се задржи само један акцент, не зато да би се указала тонска дужина, него да би се обележило место где акцент пада. Али, по правилу, свако укидање често недри проблеме који, надаље, стварају нове, а које је сасвим немогуће предвидети, ма колико се трудили да их сагледамо"

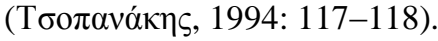

Како је назначио својевремено угледни грчки лингвиста Панајотакис

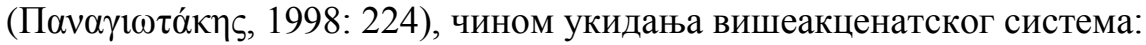

„присутни посланици су гласањем суштински укинули јединствени начин писања грчког језика, начинивши суштинску и јасну дистинкцију између историјског бележења античког и средњовековног грчког, који ће остати за остали свет вишеакценатски, а спорадично и у Грчкој, од историје писања на једноакценатском систему савременог грчког. Раскол са једном толико дугом 
традицијом изгледа да није погодио нити забринуо, а још мање осоколио неохеленисте. Нити су се чуле жалопојке нити ковања у звезде”.

Међутим, према речима некадашњег угледног грчког политичара и врсног теоретичара Ангелоса Елефантиса, „нема ниједног историјског разлога да се задржи вишеакценатски систем, пошто је он остатак постхеленистичког

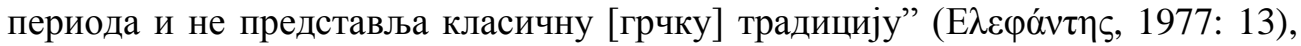
будући да „су антички Грци писали великим словима и да нису употребљавали акценте” (ПВ, 1982: 457), а да „деца у школи, учећи писање и читање, губе хиљаде часова мучећи се да савладају сложена правила акцената [који] више немају никаквог фонолошког смисла". Зато увођење једног оваквог система доприноси да „се не расипају покрети и новац: пишући и читајући монотонски, трошимо мање времена и енергије које бисмо могли

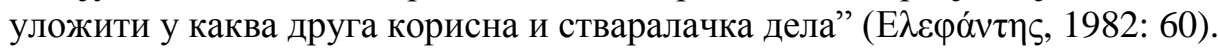

Коначним свођењем свих грчких акцената на један, акут, завршила се једна изузетно дуга фаза у којој се, између осталог, водила готово једновековна борба за и против вишеакценатског система. Она је почела с

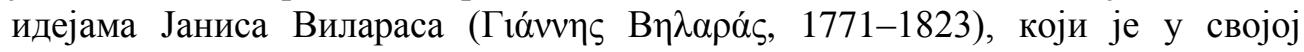

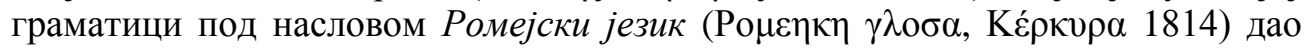
предлог и поједностављене ортографије и разлоге за укидање бележења више

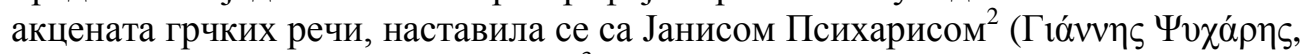

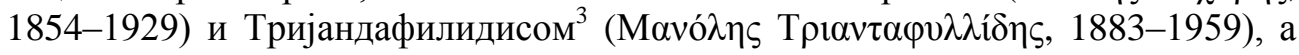
завршила са гласовитим савременим грчким лингвистима (Емануил Кријарас

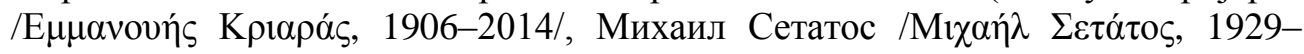

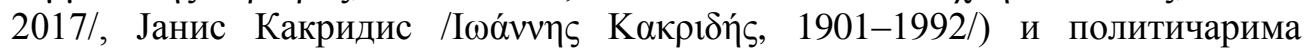
(посланицима). Истовремено, свођење свих акцената на један било је, условно речено, „козметички потез” који је, са своје стране, имао и једно дидактичко утемељење: строга правила која су регулисала који ће се акцент и аспирација писати била су, посебно на почетним нивоима описмењавања, изузетно оптерећујућа и несхватљива ученицима који су тешком муком улазила у суштину и грчке писмености и грчког правописа: будући чврсто утемељени на старим (класичним) основама и нормама, нису одговарали савременом грчком језику и његовом акценатском систему. Отуда је предлог за увођење једноакценатског система у правопис требало да пружи подстицај даљем развоју општенационалног образовања и да олакша описмењавање. Не треба заборавити важну историјску чињеницу - све до краја 1970-тих година

2 Јанис Психарис се данас сматра главним духовним представником такозваног демотичарског покрета који се залагао за увођење народног грчког језика у образовање и одбацивање катаревусе.

3 Манолис Тријандафилидис је утемељивач савремене грчке лингвистике, а својим делом Граматика савременог грчког језика (1941) први је описао све фонетске и морфосинтаксичке одлике савременог грчког језика. 
највећи проценат од укупног броја описмењеног грчког становништва је углавном имао завршену основну школу (OECD, 1980), док се ситуација знатно побошљала од почетка осме деценије прошлога столећа када је повећан број ученика у средњим школама захваљујући реформама грчког образовног система. Овај тренд се наставио и током наредне деценије. Политика уписа на државне факултете није се битније променила за све ове године: уписују их (као што их и данас уписују) само они кандидати који успеју да положе веома строге класификационе испите у оквиру државне матуре (то су такозвани „свегрчки испити”/ $\pi \alpha v \varepsilon \lambda \lambda \eta ́ v 1 \varepsilon \varsigma ~ \varepsilon \xi \varepsilon \tau \alpha ́ \sigma \varepsilon เ \varsigma /)$ који укључују и обавезно писање састава свих кандидата на одређену тему како би показали колико су писмени и елоквентни на своме матерњем језику. У тим саставима пре 1982. године свака омашка у писању, укључујући и погрешно написан или махинално испуштен акценат, доносила је кандидату негативне поене, односно драстично му је смањивала могућност да се упише на жељени факултет.

Званично увођење једноакценатског система у грчку графију 1982. године, које је било посебно потврђено и председничком декретом Константина Караманлиса (број 297; ЕК, 1982: 429-430), представља један од последњих реформистичких потеза у савременом грчком језику које је предузела социјалистичка влада (ПАСОК). Прве назнаке о пожељном модификовању, односно о поједностављењу вишеакценатског система графије савременог грчког језика, биле су дате још 1962. године (Banfi, 2010: $165)$, али су оне тек после поновног успостављања демократије и рушења војне хунте добиле своје друштвено-политичко, те историјско утемељење и оправдање.

\section{2. ГРЧКИ АКЦЕНТ И УЧЕЊЕ ГРЧКОГ КАО СТРАНОГ}

Имајући у виду да се акцент код свих двосложних и вишесложених речи мора обавезно писати, мада се и једносложне речи могу наћи под акцентом у посебним случајевима (видети о томе напред), његово усвајање врши се по принципу аутоматизма. Другим речима, акценат је, као дијакритички знак, и пратећи и обавезан део сваког написаног и/или одштампаног графичког облика било које двосложне и вишесложене лексеме. Из тог разлога се његово изостављање у писању сматра значајном правописном грешком. Према правописним решењима, акцент се никада не ставља код писања великих штампаних и писаних слова, као што су наслови у новинама, часописима, књигама и слично.

Српски полазници/студенти који уче грчки као страни језик обично у почетним фазама његовог усвајања често изоставе акцент. Ова се појава може донекле оправдати непосредном интерференцијом српске графије у којој се, по правилу, акценти никада не бележе, осим у појединим случајевима када је 
потребно направити у писању јасну разлику како би контекст био сасвим разумљив; на пример:

пао је грӓд $\neq$ пао је гра̂д

урадио сам то $\neq$ урадио сам са̂м то

И у већини других језика, попут енглеског, немачког, руског, итд., такође изостаје бележење акцената изнад слогова речи.

Основно методичко правило приликом подучавања грчког као страног језика, без обзира да ли је реч о универзитетској или о било којој другој настави, инстистира на томе да је наставник у обавези да скрене пажњу својим студентима (полазницима) да је писање акцента у грчком саставни део речи те да се аутоматизам у његовом писању најбоље може постићи једино путем класичне вежбе у виду преписивања речи. Док студент преписује реч, односно „вежба / навикава руку” и на грчки алфабет и на писање акцента, он у исти мах остварује и један изузетно важан дидактички циљ - савлађује све елементе савремене грчке ортографије која се заснива на такозваном историјском (етимолошком) начелу, што је сасвим супротно од наше правописне норме у којој важи Аделунгово начело „пиши као што говориш”4 уз Вуково проширење „читај као што је написано”.

На овом месту желели бисмо да укажемо на следеће - у свим уџбеницима грчког као страног у распону од А1 до Б2, попут:

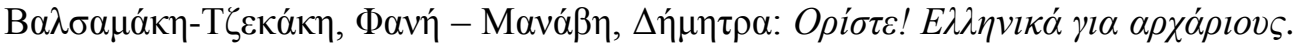

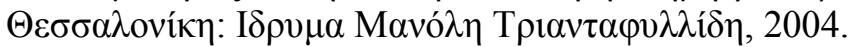

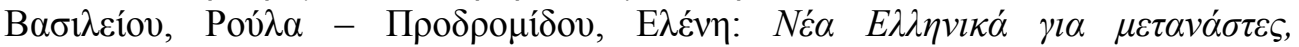

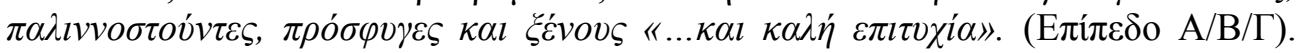

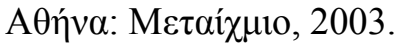

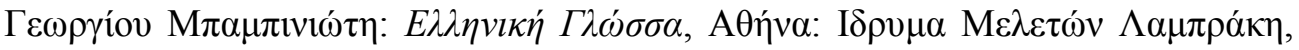
1995.

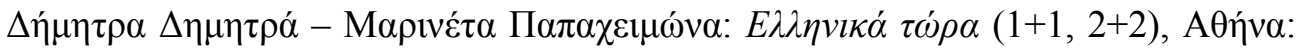

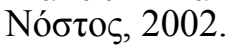

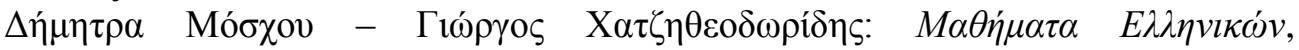
$\Theta \varepsilon \sigma \sigma \alpha \lambda$ ovíkп: University Studio Press, 2015.

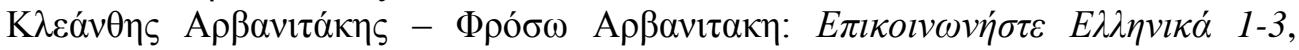
A $\theta \eta ் v \alpha: \Delta \varepsilon ́ \lambda \tau o \varsigma, 2015$.

\footnotetext{
${ }^{4}$ Аделунг је ову максиму (Schreibe, wie du sprichst) први пут изнео 1782. године у своме Магазину за немачки језик, а поновио ју је чак на четири места (Adelung, 1782: $60,61,65,136)$. Овај став ће први прихватити код нас Сава Мркаљ и поменути га при крају своје расправе о Салу дебелога јера (Мркаљ, 2010: 18).
} 


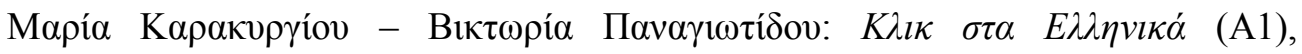

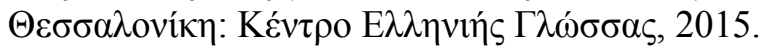

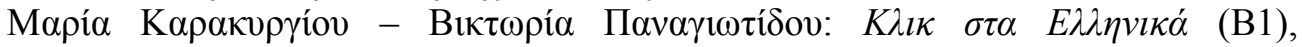

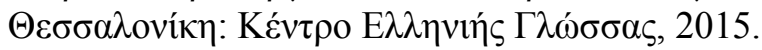

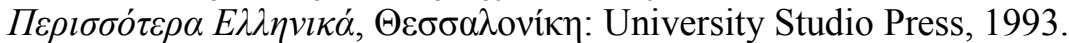

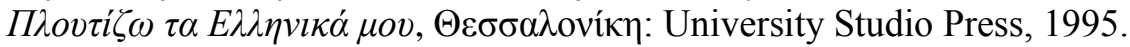

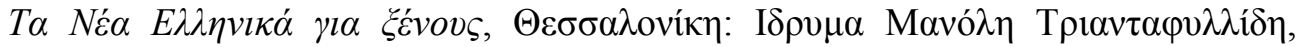
2015.

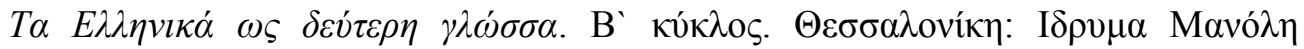

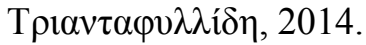

као и у граматикама савременог грчког, као што су:

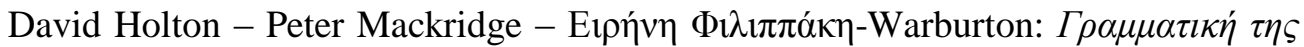

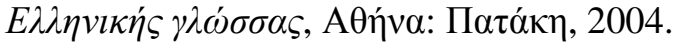

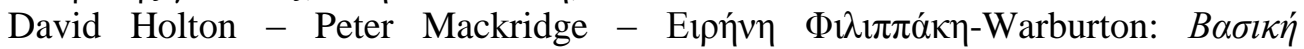

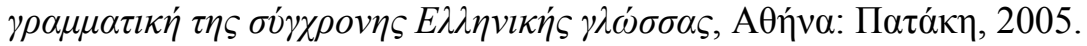

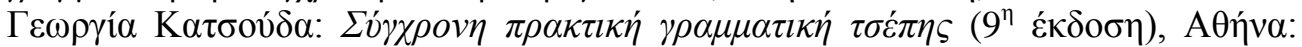
Акүора, 2008.

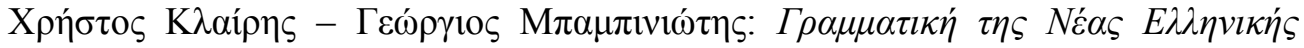

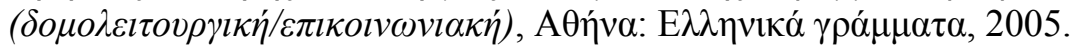

ни на једном месту се не говори кумулативно (обједињено) о правилима грчке акцентуације. Изузетак представљају две граматике:

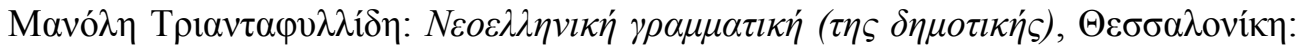

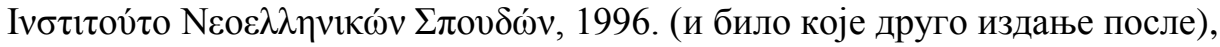

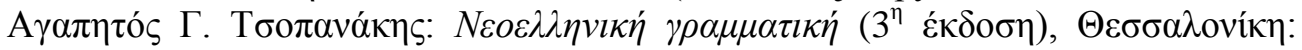

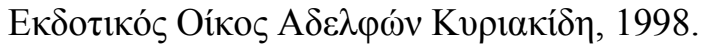

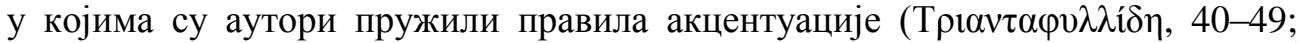

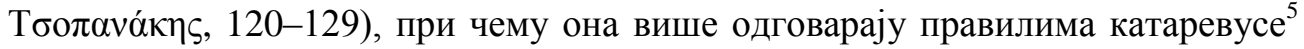
него савременог грчког језика (димотике), иако се у њиховим насловима указује да је реч о савременој грчкој граматици. У свим граматикама, као и у уџбеницима савременог грчког као страног језика, наведених и других аутора (и Грка̂ и странаца) као најважнија правила у вези с акцентуацијом дају се следећа:

\footnotetext{
${ }^{5}$ Катеревуса (к $\left.\alpha \alpha \rho \varepsilon v ́ o v \sigma \alpha\right)$, или „прочишћени” облик грчког језика, представљала је учену и узвишену форму грчког језика и стила по угледу на антички грчки. Званично је била на снази од 1830. до 1976. године када је законом укинута и када је дата

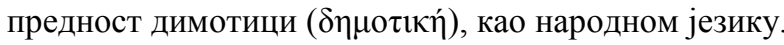


а) свака реч од два и више слога обавезно се пише с акцентом који треба да стоји на свом одговарајућем месту;

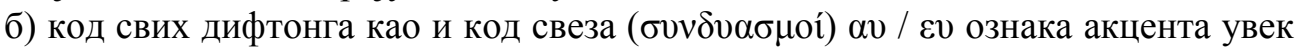

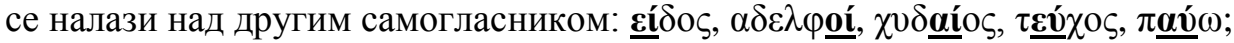

в) акцент увек претходи самогласнику као великом почетном слову: 'I $\delta \rho v \mu \alpha$, 'E$\lambda \lambda \eta v \alpha \varsigma, \underline{\mathbf{O}} \mu \eta \rho о \varsigma$, али обавезно изостаје уколико је цела реч написана

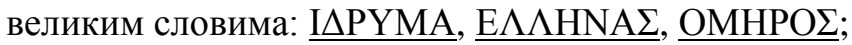

г) акцент се обавезно пише после великог слова када оно означава редни број:

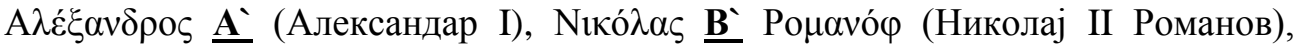
$\beta \imath \beta \lambda$ ío $\underline{\underline{\mathbf{T}}}$ (књига VI).

Како је у наведеним уџбеницима примењена комуникативна метода учења, акцент се усваја заједно са лексемама и свим њиховим морфолошким облицима који се у свакој лекцији посебно обрађују (на пример, само генитив именица женског рода једнине, или само акузатив именица мушког рода, или само презент актива и слично). Уколико имамо у виду да је грчки акцент изузетно динамичан, а што се посебно види у флексији номинала где се његово место непрекидно мења, било у једнини, било у множини, онда овакав приступ не би требало да чуди, а са методичке и дидактичке стране се сматра сасвим оправданим. То значи, другим речима, да безмало сваки морфолошки облик именице поседује, условно речено, „свој акцент” - речи у већини случајева не наглашавају се на истом слогу - те због тога ваља везати и памтити место акцента са морфолошким облицима речи.

\section{3. НЕКИМ ОПШТИМ ОСОБИНАМА ГРЧКОГ АКЦЕНТА}

Као што је добро познато, акценат је основна одлика прозодије сваког језика. Под њиме се подразумева звучни ефекат истицања једне језичке јединице, најчешће слога, или целине у односу на другу/друге суседне уз већи утрошак (ангажовање) говорних органа. У суштини, грчки акценат је прилично сложена акустичка одлика, као што је то и у сваком језику, будући да обухвата неколико засебних елемената којих у већини случајева постајемо веома свесни током нашег говора/разговора, као што су:

1. јачина изговора - указује на акустичко одређење гласа у распону од тихог до гласног, а увек зависи од вибрација гласних жица под притиском ваздушне струје у гркљану;

2. висина тона - означава укупну слушну перцепцију неког гласа, па је зато аудитивно фонетско обележје.

На основу висине тона у слушном апарату региструјемо фреквенцију (y Hz) којом је неки глас изговорен и тако га препознајемо. Приликом 
изговарања једног гласа уједно производимо и друге пратеће елементе чиме глас варира. На основу њих стварају се утисци узлазног, силазног, отвореног, затвореног, кратког, дугог, шумног, итд. тона.

3. трајање - подразумева укупно потребно време за артикулацију једног гласа или слога. Колико ће временски трајати неки глас зависи искључиво од брзине нашег говора, такозваног темпа;

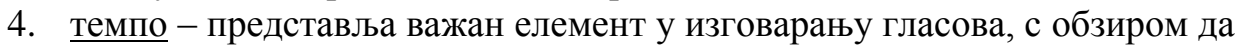
се преко њега постижу посебни акустички и емфатички ефекти током говора.

Начелно сагледано, темпо, или брзина говора, односно изговора, више је одлика реченице него речи, а настаје у зависности од начина смењивања наглашених и ненаглашених целина унутар реченичког исказа. Како је темпо индивидулна категорија, он припада искључиво домену субјективности, будући тесно везан за наша унутрашња (емоционална) стања.

5. боја гласа (тембр) - један од пратећих елемената изговора јесте боја гласа која се одређује као акустички осећај разликовања нијанси међу гласовима једнаким по висини, дужини и јачини;

6. ритам - чини начин ређања наглашених и ненаглашених слогова унутар једног језика у виду распореда акцената унутар исказа чиме се ствара крајње карактеристичан (препознатљив) образац у виду мелодије једног језика;

7. интонација - би била последњи, али исто тако битан сегмент акцента. У језику поседује две кључне функције:

a) у оквиру граматике указује на логичко разграничење између упитних и потврдних реченица;

б) у оквиру говорног чина изражава лични став говорног лица у виду посебних психолошко-емотивних ставова (чуђење, неверица, наредба...).

Према свим својим одликама, савремени грчки акценат је квантитативан и изузетно динамичан (експираторан), будући да се изражава јачином гласа или тона, за разлику од српског акцента који је мелодичан и који се изражава висином тона (силазни / узлазни акценат и њихове варијације). За разлику од српског, грчки акценат је увек везан за самогласник, најзвучнији део слога. Заједничка му је одлика са српским акцентом та да је мелодичан, али уз извесна фонолошка ограничења: тако грчки акцент никада не може бити дугоузлазан или дугосилазан, као што је то могуће у српском (на пример: суิнце, вѝљушка), него је његова реализација углавном у облику кратког, односно тренутног подизања гласа унутар слога, што се чује и у српском (слично као у речима: нӧге, ку̀нић).

Код грчког акцента уочавају се његове главне особености: 
1. јачина - самогласник под нагласком се нешто јаче и снажније изговара, невезано за место унутар неке речи. Изговор самогласника под акцентом јасније се чује од свих осталих вокала:

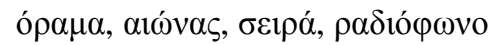

(визија, век, низ, радио)

2. дужина - у зависности од места на коме се акцент налази унутар речи, самогласник се квалитативно изговара или нешто дуже или нешто краће, што ће рећи да је он тесно повезан у овом сегменту са музикалношћу. Начелно говорећи,

А) дужи изговор представља такозвани акустички утисак веома благе узлазности у изговору речи:

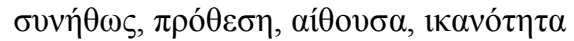

(обично, предлог, сала, способност)

Ова појава би се могла објаснити неопходном припремом говорних ограна за изговор осталих слогова, такозваним узмахом. За савремени грчки језик такозвано „гутање” ненаглашених слогова није карактеристично, што значи да се сваки слог мора јасно и гласно изговорити;

Б) краћи изговор одаје акустички утисак краткосилазности при изговору неке речи:

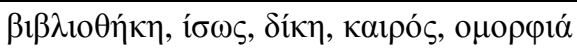

(библиотека, можда, правда, време, лепота)

У највећем броју случајева изговор савременог грчког акцента је кратак и маркиран, посебно уколико се налази на крају речи, односно на првом слогу. Дужи изговор се обично запажа код речи с акцентом било на другом, било на трећем месту (

3. музикалност - у старогрчком језику акцент је био искључиво тонски и висина је одређивала његову звучну форму: $\delta \tilde{\eta} \mu о \varsigma$ (чит. „деммос“, уп. мо̂ст), $\lambda$ б́ $о \varsigma$ (чит. „ло́гос“, уп. пе́сница).

С обзиром да у савременом грчком сви наглашени самогласници носе у себи одређену музичку ноту (квалитет) која се, како смо претходно истакли, може или нешто продужити или скратити, а што искључиво зависи од самог говорног лица, чиме се постиже акустичко-фонолошко нијансирање лика речи. То практично значи да се при изговарању грчких речи никада не може 
јавити отезање слога (као што је то случај у војвођанском говору), нити се може стећи утисак певања (као у источнохерцеговачком дијалекту српског језика), што значи да нема постакценатских дужина као у српском, већ преовлађује призвук певљивости оличен у тек благом отезању изговора самогласника. Отуда и тај акустички утисак разлике између дужег и краћег изговора. ${ }^{6}$

4. динамичност грчког акцента утиче да се јавља контрастивност $(\alpha \nu \tau \imath \pi \alpha \alpha \dot{\theta} \theta \varepsilon \sigma \eta)$ између самих вокала и слогова унутар речи.

Слогови без акцента, као што је добро познато, немају никаквог посебног смисла (као у слагалицама), што значи да акцент унутар речи указује на квантитативну разлику између два суседна и сваког наредног слога $(\rightarrow$ $\mu o ́ v o \varsigma-\tau o ́ v o \varsigma>\mu o v o ́ \tau o v o \varsigma)$. У оквиру динамичности акцент указује на посебне семантичке нијансе приликом изговарања неке речи чиме се знатно олакшава препознавање поруке. Како је грчки акценат веома покретљив, што одаје привидан утисак његове „несталности” и „неухватљивости”, савремени грчки се у том погледу знатно разликује од чешког или мађарског језика, код којих акценат, сходно фонетским правилима, стоји увек на почетку речи, или од француског, где се налази увек на крају речи. Истина је, међутим, да се грчки налази на средокраћи између ових двеју крајности.

Динамичност грчког акцента најбоље се огледа код такозваних акценатских дублета, хомофоних речи, чији је графијски лик сасвим исти, а кључно разликовање између њих постиже се једино на основу места акцента, при чему долази до јасног разликовања њихове семантике, што је одлика и српског језика (на пример: нӧвине - новѝне, про̀леће - про̀лёће̄, лѐти - лёти). Имајући у виду да је оваквих речи сијасет, са дидактичко-методичке стране веома је важно указати на ову одлику приликом подучавања грчког као страног. Овакав акцент, који се назива лексичким, запажамо у следећим паровима речи:

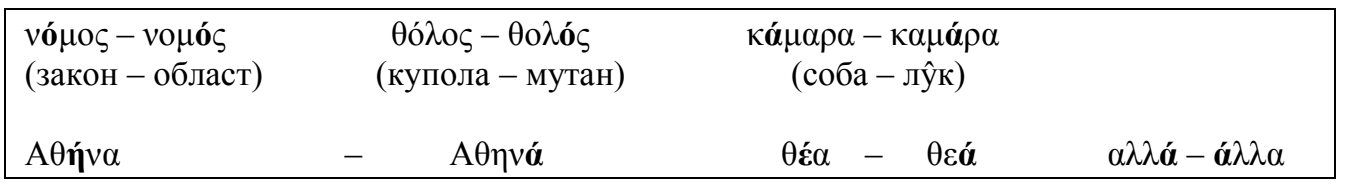

${ }^{6}$ Назначимо овде да се грчки термин $\pi \rho о \sigma \omega ́ \delta \imath$, који је у латинском преведен као accentus, управо везује за „певање”: древни грчки граматичари, попут чувеног

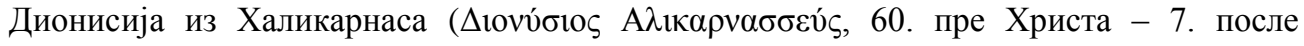
Христа), мелодију говора упоредио је са мелодијом песме, назначивши да је „(јавни) говор врста музичке науке /.../ речи укључују мелодију, ритам, варијацију” (Dionysios, 1910: 125), да је разлика између музике и говора тек један степен (тј. музички интервал; 127), а да је квантитет слогова регулисан протоком времена (131). 
(Атина, име града) - (Атина, име богиње) (поглед - богиња) /cp.p.MH/)

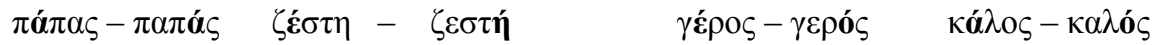

(папа - поп) $\quad$ (врућина - врућа /ж.p.j/) (старац - једар) $\quad$ (жуљ - добар)

Са друге стране, постоји и низ примера, обично су то придеви, код којих не постоји никаква семантичка разлика уколико се акценат нађе на неком другом слогу, као што су:

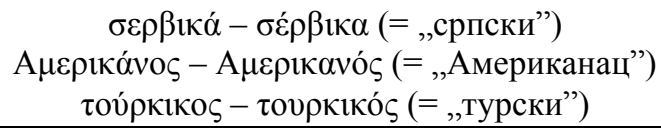

Исто тако, у поједним ретким примерима, као што су следећи акценатски дублети:

$\underline{\tau \varepsilon \lambda \varepsilon \dot{i} \omega \sigma \alpha}-\tau \varepsilon \dot{\lambda} \varepsilon 1 \omega \sigma \alpha$ (1. л. ј. индик. аор. акт. ,заврших”)

$\underline{\eta} \lambda$ íov $-\eta \dot{\lambda}$ iоv (ген. јед. м. р. ,/од/ сунца”)

разлика у положају акцента зависи искључиво од тога како се изговара спој двају самогласника унутар речи: да ли тако да се сваки слог изговара засебно (подвучени примери: /telíosa, ilíu/), што значи да се чува одговарајући положај акцента унутар речи сходно њеном морфолошком облику, или се акцент помера за једно место напред, при чему нужно долази и до акустичке промене у изговору блиских фонема (неподвучени примери: /téljosa, ílju/). У овом случају самогласнички спој је ослабљен, те, оставши без свог акцента, понаша се као неправи дифтонг. У правописном погледу, у зависности од изговора, бележиће се и одговарајући положај акцента.

Улога акцента у правилном разумевању значења речи види се и у свим оним случајевима када речи поседују приближно исти фонетски лик, при чему једино акценат у говору утиче на њихово правилно разумевање. У односу на првонаведене примере, код ових разлика се постиже и преко писања, с обзиром на то да је графијски лик сваке речи јасно одвојен:

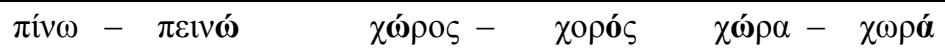

$$
\begin{aligned}
& \text { (пити - бити гладан) } \quad \text { (простор - плес / игра) } \quad \text { (земља - садржава, 3. ј. л. индик. през. акт) } \\
& \text { ó } \mu \omega \varsigma-\omega \mu \mathbf{o ́} \varsigma-\boldsymbol{\omega} \mu \rho \varsigma \quad \pi \alpha i ́ \rho v \omega-\pi \varepsilon \rho v \boldsymbol{\omega} \\
& \text { (међутим - сиров - раме) (узети - проводити) }
\end{aligned}
$$

Трећи могући случај комбинаторике јесте и онај када речи и акустички звуче исто и када се акценат налази на истом месту. Ово су такозвани 
апсолутни лажни звучни и акценатски парњаци. Разлика између њих се постиже једино преко ортографије, а у говору на основу контекста; на пример:

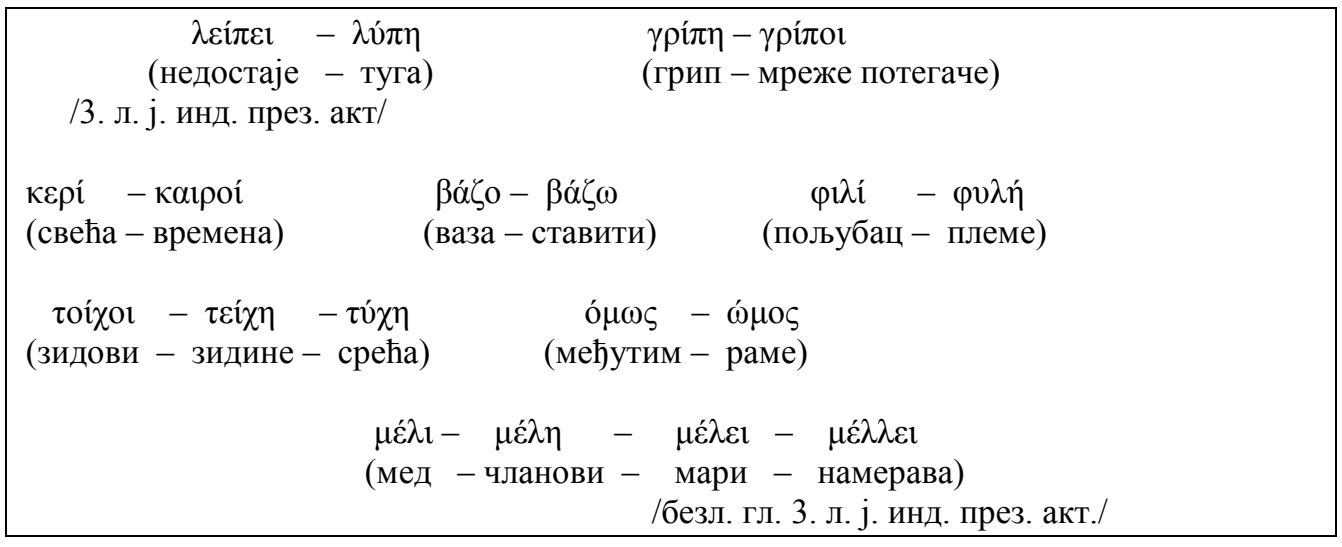

На основу показаног, види се да грчки акцент није само веома покретан, него и да поседује још три додатне функције ( $\lambda \varepsilon \imath \tau о \nu \rho \gamma i ́ \varepsilon \varsigma):$

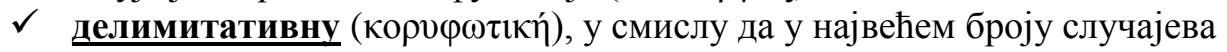
означава непосредни почетак неке речи:

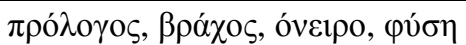

(предговор, стена, сан, природа)

или, уколико је у питању вишесложна реч, попут:

$\pi \rho \circ \varepsilon 1 \delta$ о

(упозорење, реч-повратница, неписмен)

акцент означава почетак њене тонске целине;

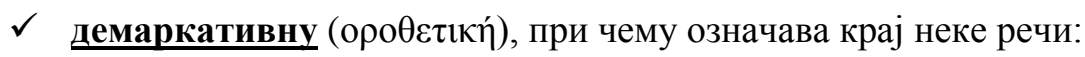

$\checkmark$ дистинктивну ( речи, уколико дође до померања места акцента унутар саме речи, како смо већ назначили.

Акцент поседује и додатну, такозвану заштитничку функцију ( 
a) спречава по правилу скраћивање самогласника, као и и његово сажимање (губљење), осим уколико то није под одређеним условима друкчије регулисано у језику; cf: $\pi \varepsilon \rho л \pi \alpha \tau \alpha \omega$ и $\pi \varepsilon \rho \pi \alpha \tau \alpha ́ \omega /-\omega ́$ /= „шетати”/, али само:

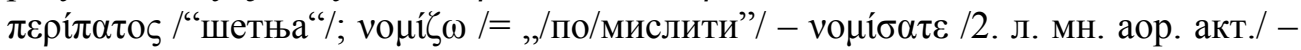

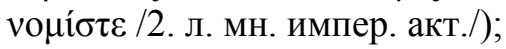

б) код једног броја речи које почињу неким ненаглашеним самогласником најчешће долази до афарезе, док акцент чува наглашени слог;

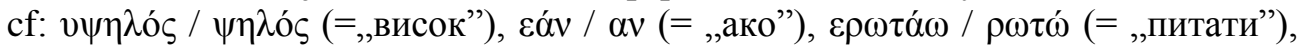

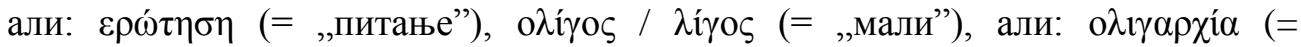

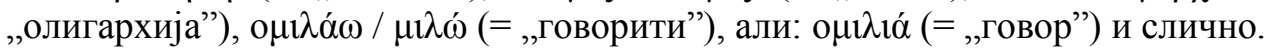

И поред тога што је правописно правило сасвим јасно када су у питању једносложне речи - оне се пишу у највећем броју случајева без акцента - а такве речи су:

- одређени чланови за сва три рода и оба броја,

- упитна заменица $\boldsymbol{\tau} \mathbf{\imath}$ (= „шта / што”),

- прости предлози ( $\boldsymbol{\mu \varepsilon}, \boldsymbol{\sigma \varepsilon}$, учени $\boldsymbol{\varepsilon} \boldsymbol{\iota}, \boldsymbol{\varepsilon} \boldsymbol{\varepsilon}, \boldsymbol{\varepsilon \kappa} . .$.$) ,$

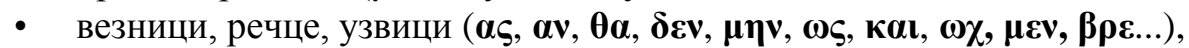

- $\quad$ глаголи $\zeta \boldsymbol{\omega}\left(=\right.$, „живети”), $\boldsymbol{\delta} \boldsymbol{\omega} \omega$ (= „деловати”) ${ }^{7}$,

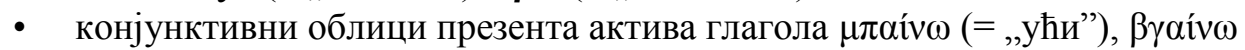

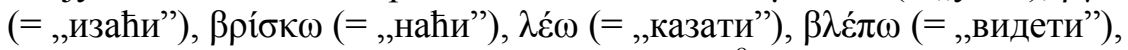
$\pi i v \omega\left(=\right.$, ,ити"): $\boldsymbol{\mu} \pi \omega, \beta \gamma \omega, \beta \rho \omega, \pi \omega, \delta \omega, \pi \iota \omega^{8}$,

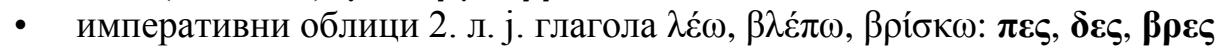

- синкопирани облик 2. л. ј. презента глагола $\theta \varepsilon ́ \lambda \omega$ /= „хтети““: $(\theta \varepsilon \dot{\lambda} \lambda \varepsilon 1 \varsigma>)$ $\boldsymbol{\theta \varepsilon}$,

- апокопирани облик предлога $\mu \varepsilon \dot{\sigma \alpha}$ (= „унутра”): $\mu \varepsilon \varsigma$

- присвојне заменице и енклитике личних заменица ${ }^{9}(\boldsymbol{\mu o v}, \boldsymbol{\sigma o v}, \boldsymbol{\tau} \mathbf{0 v} . . . \mu \varepsilon$,

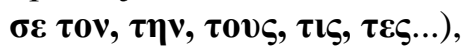

- извесне именице у номинативу и вокативу једнине: $\boldsymbol{\gamma} \boldsymbol{\eta}$ (= „земља"), $\mu \nu \varsigma$ (= „мишић”), $\theta \omega \varsigma$ (= „шакал”), $\varphi \omega \varsigma$ (= „светлост”),

- $\quad$ временски прилог $\chi \tau \varepsilon \varsigma$ (=, ,јуче")

- бројне једносложне непроменљиве именице и описни придеви који су

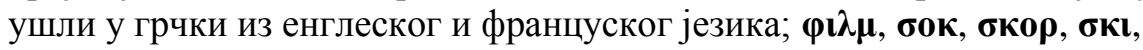

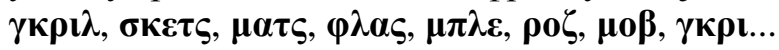

\footnotetext{
7 Само у свим облицима једнице и у трећем лицу множине индикатива презента актива.

${ }^{8}$ Код свих наведених глаголских облика акцент се не бележи у сва три лица једнине и трећег лица множине (cf: $v \alpha \mu \pi \omega / \mu \pi \varepsilon เ \varsigma / \mu \pi \varepsilon \mathrm{l} / \mu \pi \mathrm{ovv})$.

9 Стицајем околности, између њих нема никаквих разлика у морфолошком и у ортографском погледу, а право значење неког облика види се једино унутар контекста.
} 
ипак постоје случајеви када акцент постаје њихов важан дистинктивни графички елемент, будући да се тада постиже разликовање њихових значења, као што показују наредни примери:

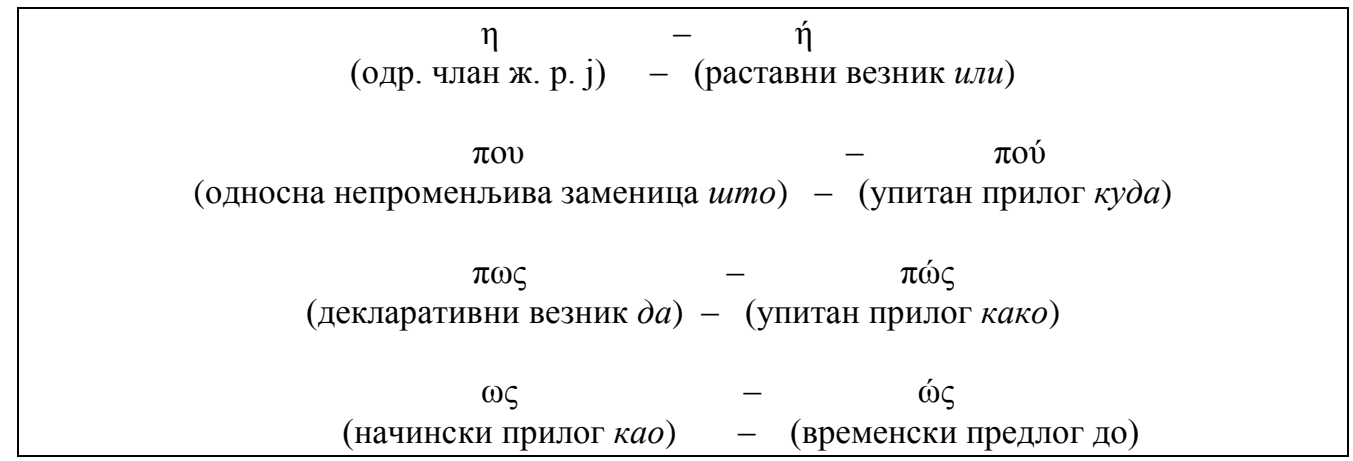

Ненаглашени енклитички облици генитива личних заменица имају акценат једино под условом уколико постоји могућност да се схвате не као личне већ као присвојне заменице током читања; на пример:

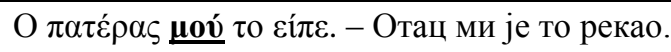

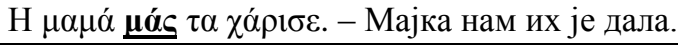

Овде је важно назначити да се у свим оваквим конструкцијама постиже језичка економија и избегава се хаплологија; cf:

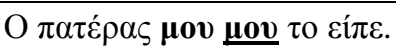

Мој отац ми је то рекао.

Према грчком правопису, у групу једносложних речи сврставају се и све оне чији се неправи дифтонг и даље чује као у примеру:

a) акузативног предлога $\underline{\boldsymbol{\iota} \alpha}$,

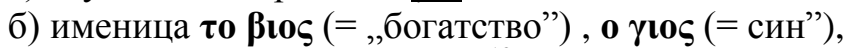

в) прилога $\underline{\boldsymbol{\pi} \boldsymbol{\alpha} \boldsymbol{\alpha}}\left(=\right.$, ,већ”) и $\underline{\boldsymbol{\pi}}^{10}$ (= ,више"),

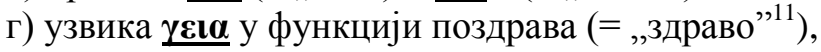

\footnotetext{
${ }^{10}$ Овај прилог се јавља само у оквиру аналитичке компарације придева: $\varepsilon \lambda \alpha \varphi \rho o ́ \varsigma-\pi 10$ $\varepsilon \lambda \alpha \varphi \rho o ́ \varsigma-o ~ \pi t o ~ \varepsilon \lambda \alpha \varphi \rho o ́ \varsigma$ (лак - лакши - најлакши).
} 
д) основног броја за женски род $\boldsymbol{\mu} \boldsymbol{\alpha}(=$, ,једна"), који функционише у језику и као неодређени члан женског рода,

ђ) основног броја за мушки и женски род $\underline{\boldsymbol{\tau} \rho \varepsilon є ~(=~ „ т р и ”), ~}$

е) упитне заменице $\underline{\boldsymbol{\pi} \mathbf{0 l 0}}(=$,„ко).

Међутим, ове се речи могу наћи под акцентом само у случајевима када је потребно или извршити емфазу у реченици; на пример:

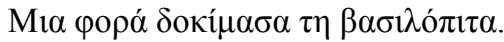 \\ Једном сам пробао чесницу.}

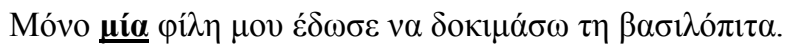

Само ми је једна пријатељица дала да пробам чесницу.

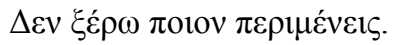

Не знам кога чекаш.

Пoı́́v $\pi \varepsilon \rho \mu \varepsilon ́ v \varepsilon 1 \zeta ; !$

Кога [то] чекаш?!

или када се знатно мења изговор речи, као што је то у примеру наредног пара речи:

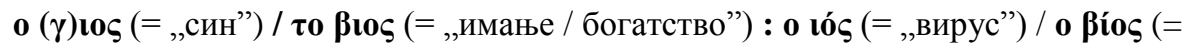

$$
\begin{aligned}
& \text { „живот”) }
\end{aligned}
$$

где је улога акцента у изговору (али и у писању) веома важна: уколико се изговоре или напишу било као једносложне /jos, vjos/ или као двосложне речи liós, víos/, проистиче и њихово значење.

\section{4. О ДИНАМИЧНОСТИ ГРЧКОГ АКЦЕНТА КОД ИМЕНСКИХ РЕЧИ}

Иако смо до сада назначили да је у савременом грчком природа акцента динамична, његово место унутар речи је строго фиксирано. Сходно правилима грчке акцентуације, устоличеним још од античког доба, акцент се може наћи на једном од три могућа места у речима, а из претходно наведних примера то је позиција:

${ }^{11}$ Наш поздрав „здраво” је калкиран према наведеном грчком говорном елидираном облику. У суштини, реч је о именици vүві́ (=, ,здравље") која се и данас веома често

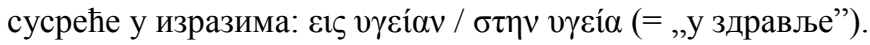




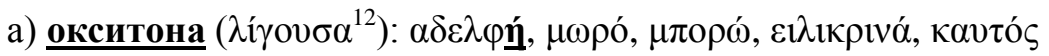

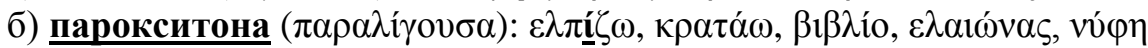

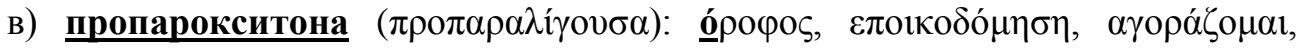
$\alpha ́ \sigma \chi \varepsilon \tau \alpha, \delta \omega ́ \delta \varepsilon \kappa \alpha$.

Међутим, методички је изузетно важно назначити студентима (полазницима) да је позиција акцента у једној речи увек у директној зависности не од укупног (збирног) броја слогова једне речи, него од одређених унутрашњих услова, као што је морфолошка промена речи (попут деклинације) или деривација (префиксација или суфиксација). У односу на грчку, за српску прозодију нису карактеристичне речи с акцентом на првом месту, те оне на почетку учења грчког умеју да задају прилично муке почетницима.

Са друге стране, иако строго фиксиран, грчки акценат је веома покретан унутар три наведене позиције, што значи да се у готово свакој речи може наћи на различитом слогу баш као што га и у породицама речи с истим кореном (основом) можемо наћи на различитим местима; на пример:

$$
\begin{gathered}
\theta \underline{\hat{\varepsilon}} \lambda \omega-\theta \underline{\mathbf{\varepsilon}} \lambda \eta \sigma \eta-\theta \varepsilon \lambda \underline{\underline{q} \sigma \varepsilon ı \varsigma}-(\eta) \theta \varepsilon \lambda \eta \mu \underline{\varepsilon} v o \varsigma \\
\text { желети - жеља - жеље - жељен }
\end{gathered}
$$

На пољу деривације динамичност грчког акцента се такође јасно испољава, будући да на његово место унутар неке изведене речи утичу

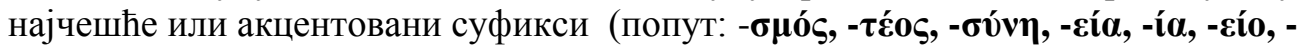

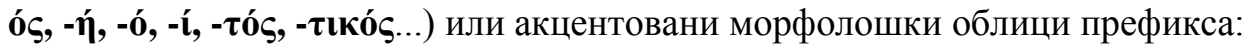

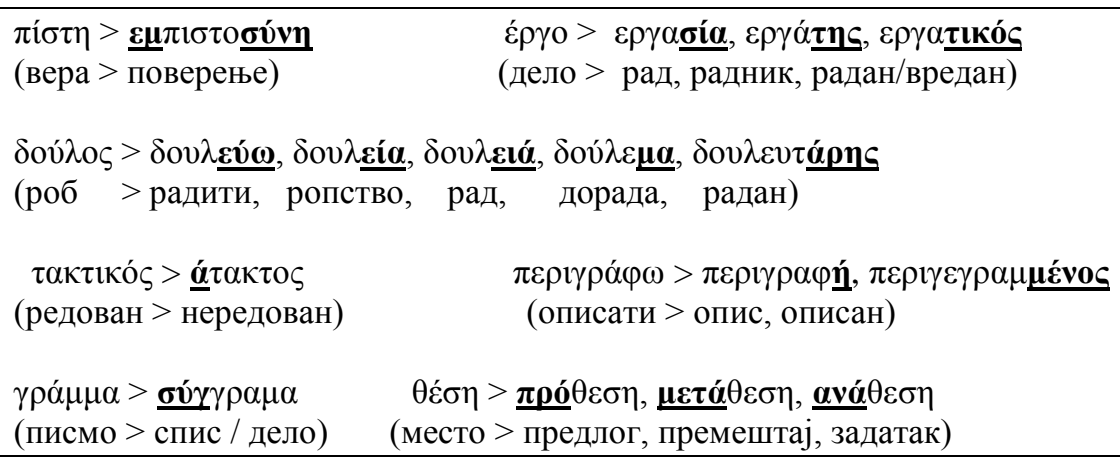

12 Занимљиво би било овде истаћи да се наведени грчки термини односе на позицију слога унутар речи који носи акцент (у слободнијем преводу: „крајњи”, „преткрајњи”, „допреткрајњи”). 
Исто тако, унутар флексије вишесилабичких именица сва три рода код којих се акценат у номинативу једнине налази на пропарокситоној позицији долази до померања акцента из два разлога:

- $\quad$ код флексије именица средњег рода номинтива основе на - $\boldsymbol{\mu \alpha}$ и $-\boldsymbol{\mu о}$,

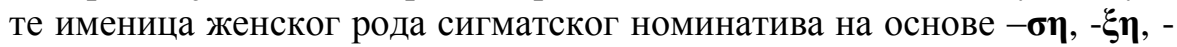
$\boldsymbol{\psi} \boldsymbol{\eta}$, долази до проширења основе за слог више у генитиву једнине и у свим облицима множине, те се тако акценат мора померити за место унапред, с обзиром да никако не може стајати на четвртом месту с краја, како је већ истакнуто;

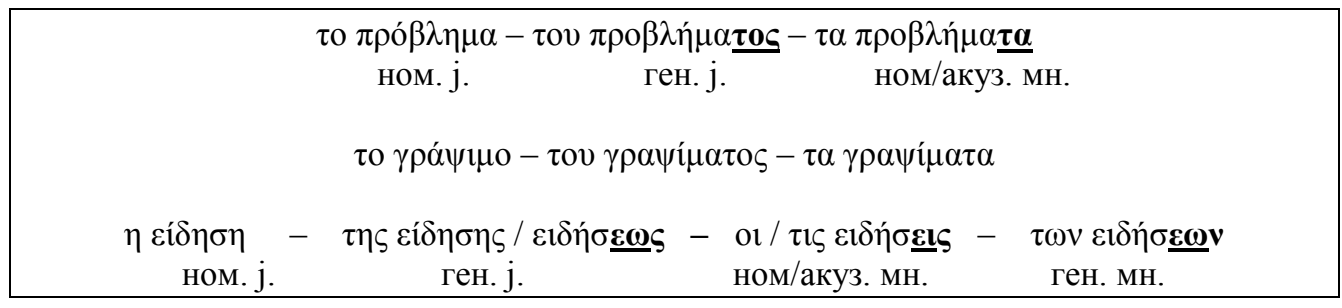

Овако померање акцента условљено је непосредним историјским развојем грчког језика: наиме, именице средњег рода очувале су истоветну промену у једнини и множини као из античког периода, док су оне женског рода истоветан морфолошки лик сачувале само у множини, не и у једнини ${ }^{13}$.

Померање акцента код указаних именица женског рода у номинативу и акузативу множине такође је условљено историјски - њихов морфолошки лик сачувао је све одлике деклинације из класичног грчког, а завршни слог у множини у облику некадашњег дугог дифтонга ${ }^{14}$ условио је да се положај акцента помери за једно место уназад, чиме је сачувана полазна пропарокситона позиција акцента.

- $\quad$ услед наслеђених фактора, и поред тога што остаје исти број слогова у речи. Код пропарокситоних именица мушког и женског рода на -о $\mathrm{y}$ генитиву једнине те у генитиву и акузативу множине акцент се

13 Данашње именице женског рода основе - $\boldsymbol{\boldsymbol { \eta }}$, - $\boldsymbol{\xi} \boldsymbol{\eta},-\boldsymbol{\eta}$ прешле су из некадашње треће деклинације у прву. У старогрчком акцент је могао стајати на трећој позицији с краја једино у колико је ултима била кратка. Како су се ове именице завршавале у једнини на наставак -1ร, чија је самогласник била кратка (јота), у множини је кратка ултима постала дуга, што је узроковало логично померања акцента за једно место напред, како би се задржало његово исто место, али не и почетна позиција.

${ }^{14} \mathrm{y}$ данашњем изговору он је монофтонгизован и носи гласовну вредност /и/. 
помера, с обзиром да је самогласник оv (,,““) дуг ${ }^{15}$. Слично је и са генитивним наставком множине: некада је омега / $\omega /$ заиста поседовала вредност двоструког гласа „о” (о+o), што је условљавало да се због саме дужине изговора акцент у косом падежу помери (данас у изговору између ње и омикрона /o/ нема апсолутно никакве разлике):

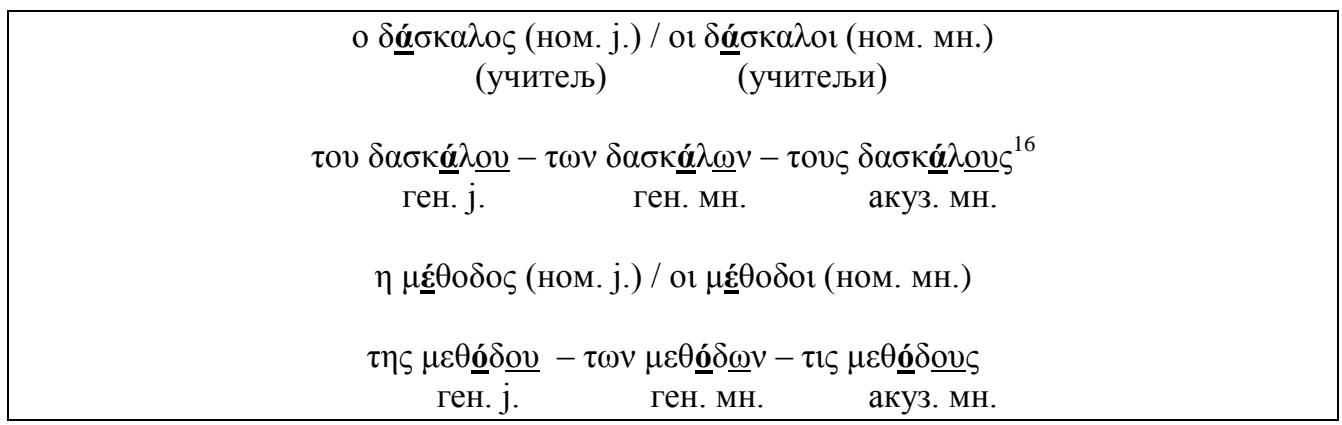

Исти случај дуге омеге која нужно условљава померање акцента сусрећемо и код прилога изведених од пропарокситоних придева путем наставка - $\omega \varsigma$, на пример:

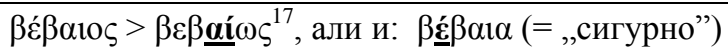

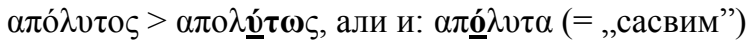

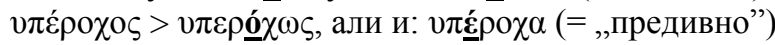

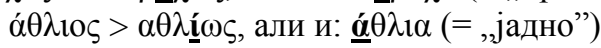

као и код већ наведених именица средњег рода на - $\boldsymbol{\mu \alpha}$, затим код именица женског рода формираних путем наставка на $-\boldsymbol{\tau} \boldsymbol{\eta} \tau \boldsymbol{\alpha}$ или код основног броја четири у генитиву множине:

$$
\begin{aligned}
& \tau \text { о } \mu \underline{\boldsymbol{\alpha}} \theta \eta \mu \alpha-\tau \omega \nu \mu \alpha \theta \eta \mu \boldsymbol{\alpha} \tau \omega \nu \text { (= "лекција" / "час") } \\
& \eta \delta v v \alpha \tau \underline{\underline{o}} \tau \eta \tau \alpha-\tau \omega v \delta v v \alpha \tau o \tau \underline{\eta} \tau \omega v(=\text { "могућност") } \\
& \tau \underline{\varepsilon} \sigma \sigma \varepsilon \rho 1 \varsigma / \tau \underline{\varepsilon} \sigma \sigma \varepsilon \rho \alpha-\tau \varepsilon \sigma \sigma \underline{\alpha} \rho \omega v(=\text { "четири") } \\
& \text { м.-ж. род / ср. род }
\end{aligned}
$$

\footnotetext{
15 По свему судећи, још пре класичног доба изговарао се не као дуги монофтонг, већ као два засебна гласа (о+ помућено у), што је почетно омогућило померање акцента у генитиву.

${ }^{16}$ И код ових именица ултима је у номинативу једнине била кратка, па се померање акцента одвијало под истим условима као и код претходно објашњених именица женскога рода.

17 Ови облици су пре резервисани за званични или за виши језик и стил, посебно у писању.
} 
Код једног броја именица померање њиховог акцента се може најпростије објаснити као последица наслеђеног историјског развоја флексије грчког језика. Тако се код парокситоних и пропарокситоних именица женског рода које се завршавају на флективни наставак $-\boldsymbol{\alpha}$ и $-\boldsymbol{\eta}$ акцент нужно помера према окситоној позицији у генитиву множине што је последица некадашње контракције вокала:

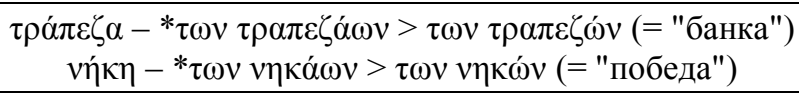

Историјски разлози су такође обележили и померање акцента у генитиву деклинације основног броја један за мушки и средњи род, те броја три за сва три рода:

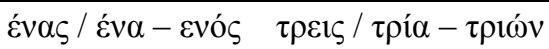

Савремени грчки развио је и флексију именица средњег рода на неакцентовану јоту $(-\mathbf{\imath})$ непознату класичном грчком код које у генитиву једнине и множине долази до обавезног померања акцента с основе на морфолошки наставак:

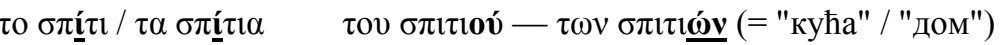

Са дидактичко-методичке тачке важно је указати на следећу особеност грчког акценатског система: постоје речи код којих никада не долази до промене акцента током њихове деклинације. То су такозване народне речи ( $\lambda \alpha \ddot{к} \kappa \dot{\varepsilon} \lambda \lambda \dot{\varepsilon} \xi \varepsilon 1 \zeta)$ које се везују за непосредан материјални и физички свет Грка, за њихов рад и свакодневницу те се зато, по своме карактеру, оштро одвајају од речи које припадају узвишеном и ученом језику и стилу књижевности, религије и филозофије. Такве су:

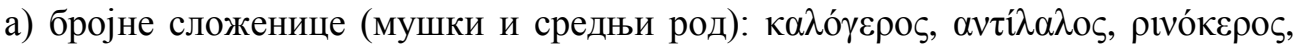

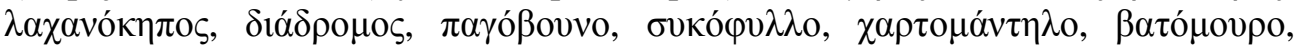

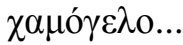

б) речи насталих деривацијом: $\delta \alpha \sigma \kappa \alpha ́ \lambda \alpha$, vобоко́ $\mu \alpha . .$.

Додатно, акцент се неће померити и код речи сачуваних из ранијих фаза грчког језика (уз одређене морфолошко-фонетске адаптације) или

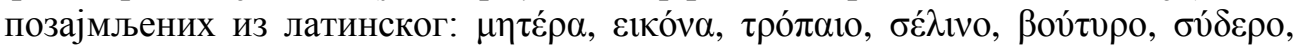

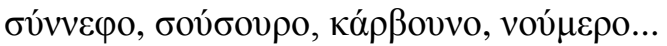

Да би студенти/полазници лакше увидели да ли ће се током деклинације место акцента променити, потребно им је скренути пажњу на 
следеће: акцент се никада не помера са своје почетне позиције приликом деклинације у једнини и у множини код:

а) именица женског рода формираних путем акцентованих морфолошких

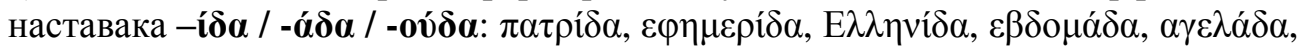

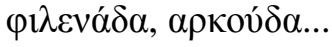

б) двосложних и вишесложених именица мушког рода које се завршавају на:

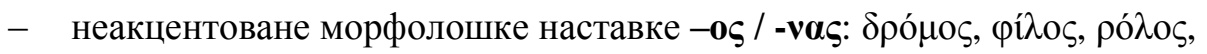

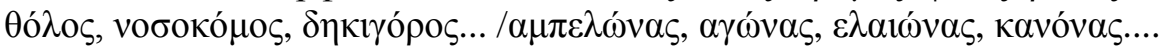

- акцентоване морфолошке наставке:

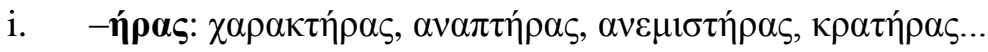

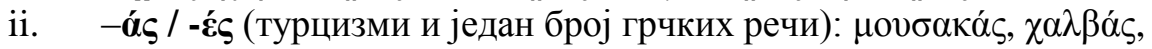

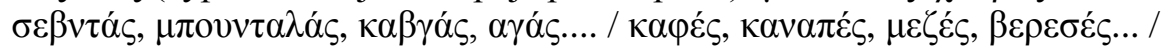

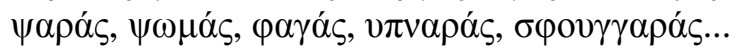

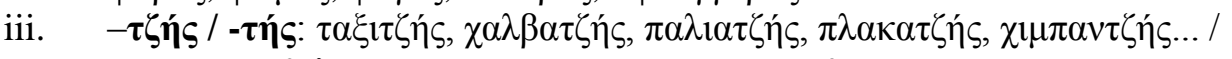

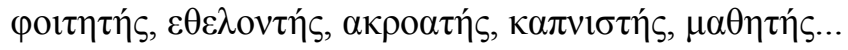

в) двосложних и вишесложених именица средњег рода на неакцентован

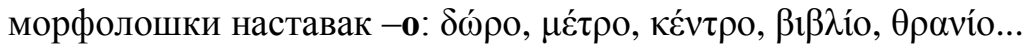

г) код придева и заменица, без обзира на ком се месту налази акцент. Изузетак

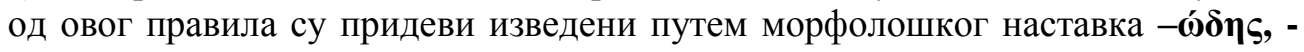

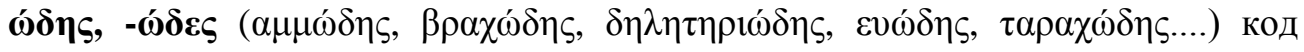
којих је у генитиву множине за сва три рода акцент померен за једно место ($\omega \delta \omega \dot{v})$.

Основно правило акцентуације каже следеће: уколико је неки придев поименичен у именицу мушког, женског или средњег рода, тада се обавезно примењује правило акцентуације сходно деклинацији којој та именица припада, и то без икаквих изузетака.

Једна од особености савременог грчког је и то да се и у говору и у писању често сусрећемо са речима које нужно носе два акцента, и то увек у ситуацијама када након речи с акцентом на пропарокситони следи атона реч. У тим и таквим случајевима артикулација мора бити изведена у једном даху, без наглих прекида. То је директна последица саме прозодије грчког језика која не дозвољава да се ненаглашене речи губе (гутају) и која захтева да се очува мелодија као и правилан ритам смене наглашених и ненаглашених целина унутар исказа, на пример: 


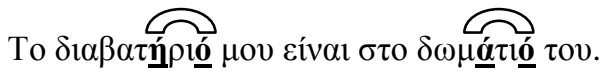 \\ (Мој пасош је у његовој соби)}

На тај начин настаје такозвани луิк фразе (у музици му је одговарајући термин легато) како би акустички исказ био што јаснији и разговетнији.

\section{5. О ДИНАМИЧНОСТИ ГРЧКОГ АКЦЕНТА КОД ГЛАГОЛА}

Када је реч о глаголима, грчки акцент показује и статичке и динамичке

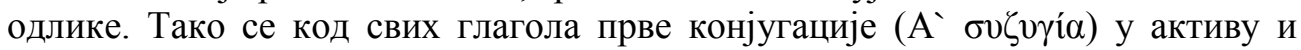
пасиву презента акцент увек налази на основи: у активу акцент је на парокситоном месту, у пасиву на пропарокситоном:

\section{$\beta \lambda \underline{\varepsilon} \pi \omega / \beta \lambda \underline{\varepsilon} \pi 0 \mu \alpha 1 \quad \alpha \gamma o \rho \underline{\alpha} \zeta \omega / \alpha \gamma o \rho \underline{\alpha} \zeta o \mu \alpha 1 \quad \pi \varepsilon \rho 10 \rho i \zeta \zeta \omega / \pi \varepsilon \rho 10 \rho i ́ \zeta o \mu \alpha 1 \quad \mu о \rho \varphi \omega ́ v \omega /$ $\mu о \rho \varphi \omega ́ v o \mu \alpha \imath$}

Приликом подучавања грчког као страног важно је увек имати на уму следеће:

док је у активу кроз целу парадигму акцент статичан, у пасиву у првом и другом лицу множине акцент се помера за једно место, прелазећи на наставак, услед проширења морфолошког наставка за један слог, док у трећем тежи да се врати на почетну позицију, будући да нема додатног слога:

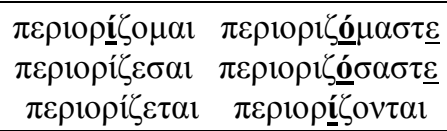

$>$ Парадигме индикатива аориста и имперфеката ових глагола и у активу и у пасиву такође показују сличност са приказаном ситуацијом: и у њима акцент тежи да остане што је могуће више статичан, увек на пропарокситоном месту, с тиме што:

А) код двосложних глагола у активу, основи обавезно претходи аугмент $\varepsilon$ - / $\eta$ , који носи акцент у свим лицима једнине као и у трећем лицу множине (cf:

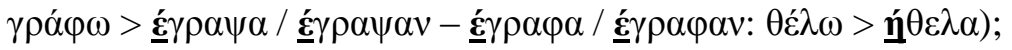

Б) у индикативу аориста пасива акцент у једнини остаје на глаголској основи, у прва два лица множине прелази на наставак због проширења слога (cf: $\gamma \rho \underline{\underline{\alpha}} \varphi о \mu \alpha \imath>\gamma \rho \underline{\alpha}(\varphi \tau \eta \kappa \alpha-\gamma \rho \alpha \varphi \tau \underline{\underline{n}} \kappa \alpha \mu \varepsilon$ / $\gamma \rho \alpha \varphi \tau \underline{\underline{n}} \kappa \alpha \tau \varepsilon)$, а у трећем лицу се враћа на основу ( $\gamma \rho \underline{\alpha} \varphi \tau \eta \kappa \alpha \nu)$; 
В) у имперфекту пасива акцент у свим лицима увек је на наставку, с изузетком трећег лица множине где се враћа на глаголску основу (cf: $\gamma \rho \alpha ́$ фо $\mu \alpha \iota$

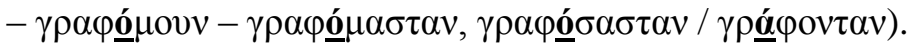

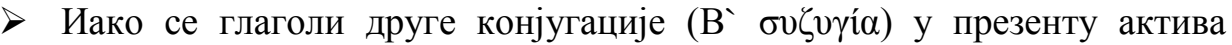
препознају по карактеристичној наглашеној окситоној омеги (-ஸ́), уочава се један број глагола код којих постоје и неконтраховани и

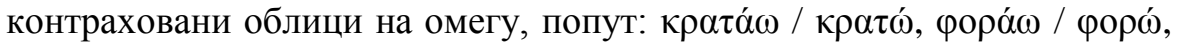

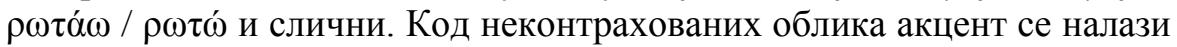
на основи глагола. Без обзира на то којој подгрупи глагол припада, његови пасивни облици, укључујући ту и депонентне глаголе, у индикативу презента имају акцент на наставку кога чувају у целој парадигми:

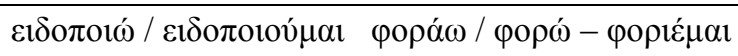

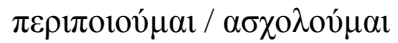

при чему:

I. у индикативу аориста актива и пасива акценат остаје увек на пропарокситоној позицији: у једнини и у трећем лицу множине почива на глаголској основи, у множини је на наставку ${ }^{18}$,

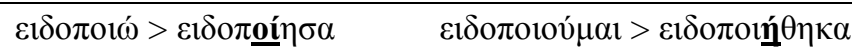

II. у индикативу имперфекта актива и пасива налази у свим лицима на акцентованом наставку:

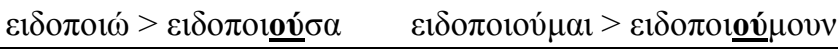

\section{6. УМЕСТО ЗАКЉУЧКА}

Из нашег најосновнијег прегледа о грчком акценту и о његовом функционисању у савременом језику може се увидети да је његово правилно усвајање, тачније речено усвајање његовог одговарајућег положаја унутар речи, од изузетне граматичко-морфолошке, правописне и ортоепске важности.

18 Овде би требало обратити пажњу на следеће: постоје глаголски облици који су у употреби у ученом и званичном језику и стилу, а потичу из класичног грчког: код њих

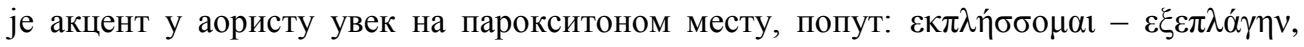

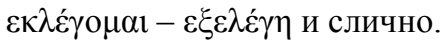


Како је грчки акцент динамичан, односно веома помичан унутар три једине могуће позиције унутар речи на којој се може наћи, приликом савлађивања како основних одлика грчке граматике тако и целокупног вокабулара грчког језика, неопходно је указивати студентима (полазницима) који уче савремени грчки као страни на сва правила његовог појављивања. У том погледу јединство између морфолошких облика и одговарајућег места који акцент у њима има заиста може умногоме допринети да се што лакше и брже савладају оба сегмента.

Највећу покретљивост грчки акцент показује код деклинације именица сва три рода, што ће рећи да се стиче утисак како је он ту и највише неуједначен. Међутим, чињенице говоре сасвим супротно: да у деклинацији именица акцент ипак тежи да што више остане на истом оном месту које има у номинативу једнине. Тамо где није то могуће, из разних разлога (морфолошких, фонетских, лексичких, итд.), акценат се нужно примиче самом крају речи и то минимално (обично за једно место напред, некада за два, као

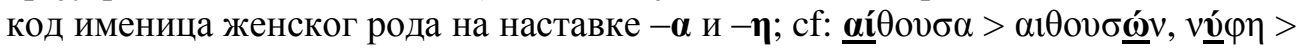
$v v \varphi \underline{\underline{\omega}} v)$ и враћа се на почетну позицију чим му то услови дозволе.

Када је реч о глаголима и о њиховим конјугационим парадигмама, и ту акцент тежи да у свим лицима, временима и начинима, без обзира на то којој конјугацији глагол припада, сачува своју почетну позицију, при чему његово померање за једно место обично долази због проширења морфолошког наставка за један слог. Ово је посебно видљиво у наставцима за прво и друго лице множине индикатива презента, аориста и имперфекта актива и пасива. Тиме што се позиција акцента код глагола чува јасно показује да код грчких глаголских парадигми постоји и потреба и тежња да се он што више удаљи од краја речи.

За разлику од именица, у деклинацији придева, сходно правилима акцентуације, позиција акцента увек остаје непромењена, без обзира на род, број и падеж. Изузетак од овог правила јесу придеви формирани наставком -

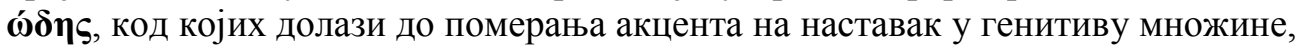
као и поименичавање придева где се тада примењују сва правила акцентуације сходно роду и морфолошком облику новонастале именице.

Како смо показали, једносложне атоне речи, које су махом и хомографи и хомофони, у писању увек бивају акцентоване како би се указало на потребну њихову семантичку разлику, а у говору су акустички посебно обележене. Исто тако, често се запажа у писању, а чује у говору, да једна вишесложена реч носи два акцента - такве су све пропарокситоне именице којима следи нека ненаглашена реч, по правилу присвојни придев. На тај начин се задржава и чува мелодија и ритам грчког језика, односно правилно низање наглашених и ненаглашених слогова унутар исказа. 


\section{СКРАЋЕНИЦЕ}

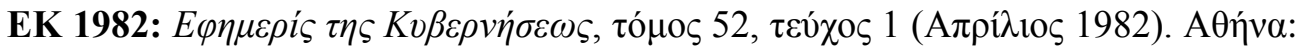

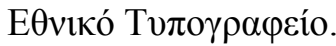

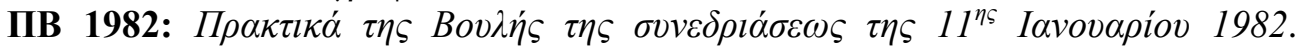

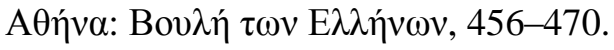

OECD 1980: Educational Policy Planning: Educational reform policies in Greece. Paris

\section{ЛИТЕРАТУРА}

Adelung, J. C. (1782). Magazin für die Deutsche Sprache, Band 1. Leipzig.

Banfi, E. (2010). La Grecia moderna e la formazione della Néa Ellinikí Koiní. Linguistica 50/3, 157-168.

Dionysius of Halicarnassus. (1910). On Literary Composition (edited by W. Rhys Roberts). London: Macmillan and Co.

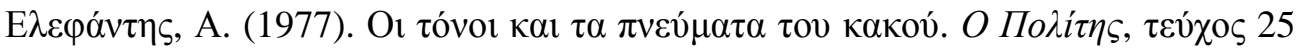

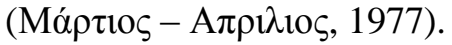

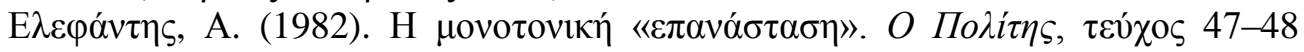

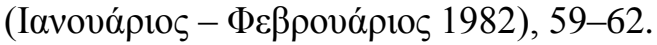

Мркаљ, С. (2010). Сало дебелога јера либо азбукопротрес (приредио Александар Младеновић). Нови Сад: Матица српска [Mrkalj, S. (2010). Salo debeloga jera libo azbukoprotres (priredio Aleksandar Mladenović). Novi Sad: Matica srpska]

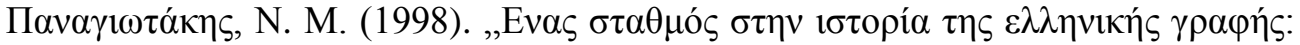

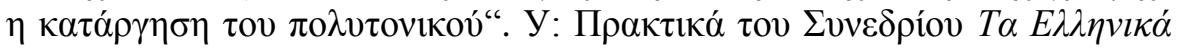

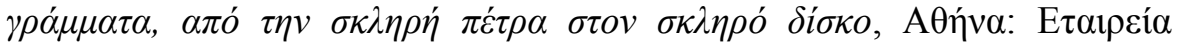

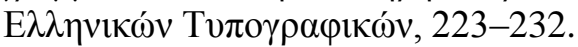

Tonnet, H. (1984). Manuel d'accentuation grecque moderne (démotique). Paris: Klincksieck.

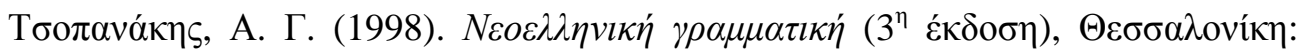

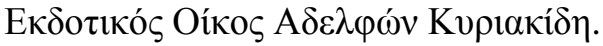

Vendryes, J. (1945). Traité d'accentuation grecque. Paris: Klincksieck. 
Predrag J. Mutavdžić

University of Belgrade

Faculty of Philology

Deparment of Neohellenistic Studies

\title{
ON THE IMPORTANCE OF ACCENT IN TEACHING MODERN GREEK AS A FOREIGN LANGUAGE
}

\begin{abstract}
Summary
According to the rules of the accentuation of Modern Greek, every word which consists of two and more syllables must be written with the acute accent above the syllable which carries the stress. As Modern Greek is a language with lexical stress, any bi- and polysyllabic word written without it is usually considered misspelled. For more than 1500 years Greeks used in writing the so-called polytonic system of accentuation, the features of which did not correspond to the present accentuation of Modern Greek. From a methodological and didactic point of view, the main task of any teacher of Modern Greek is to offer his students a good insight into the role and meaning of stress in the Greek language. Although the very position of stress within any Greek word is firmly limited, it is highly movable on the other hand. This could be best seen in declensions of nominals as well as in derivations of nouns and nominals, where the stress on the root usually tends to override its original position and pass on to inflectional suffixes. As there are a large number of Greek homophone words, the final position of stress contributes significantly to the precise meaning of the lexeme (cf: $\theta \underline{\mathbf{o}} \lambda \mathrm{o} \varsigma-\theta \mathrm{o} \lambda \hat{\mathbf{o}} \varsigma$ ). In the Present Tense (active / passive voice) as well as in past tenses, the Aorist and the Imperfect (active / passive voice), verb forms tend to strongly preserve the position of their stress, which is either penultimate or antepenultimate. Usually monosyllabic words are atonic ones, but in some cases some of them have to be marked by stress in writing in order to avoid confusion and misunderstanding of their meaning with the same homophone word without stress.
\end{abstract}

Keywords: modern Greek, stress, monotonic system, rules, dynamicity, morphology.

Примљено: 19. 8. 2018. Прихваћено: 20. 9. 2018. 